\title{
Bilingual Education: Environmental Ecology in CLIL Classroom
}

\author{
Shu-Yuan Chang ${ }^{1, *}$ Hsu-Hui Cheng ${ }^{2}$ \\ ${ }^{1}$ School of Foreign Languages, Zhaoqing University, Zhaoqing 526061, China \\ ${ }^{2}$ School of Environmental and Chemical Engineering, Zhaoqing University, Zhaoqing 526061, China \\ *Corresponding author. Email: 2145632932@qq.com
}

\begin{abstract}
As a form of bilingual education, Content and Language Integrated Learning (CLIL) teaching methodology offers a significant contribution to empowering students' intercultural communication. In a globalized world, schools face the challenges of multilingual and multicultural societies. Students of various levels should be equipped with the intercultural communicative competence while learning subject content. Through CLIL teaching approach making meaning and shaping the academic knowledge and experience, authentic communication in class can be achieved in short periods of valuable teaching time. This study aims to provide a CLIL teaching of Environmental Ecology to show how students learn the academic language to address the key concepts and also become aware of the hidden cultural codes. This CLIL course is the intersection of content, cognition and language which not only engages students in cognitive activities and raises their eco-cultural consciousness but also improves their ability to express their thoughts appropriately and boosts their motivation in subject and language learning.
\end{abstract}

Keywords: bilingual education, Environmental Ecology, CLIL teaching, intercultural communicative competence, cognitive activities

\section{INTRODUCTION}

As its definition, Content and Language Integrated Learning (CLIL) teaching methodology is concerned with the learning of content and a foreign language. This approach is proposed by Finnish scholar David Marsh in 1994. Because of its integrative nature, the CLIL curriculum contains four components: content, communication, cognition and culture [1]. The 4CsFramework offers a way to clarify teaching aims and students' learning outcomes [2].

In the past, various subjects in school education such as mathematics, history, natural sciences, health education and music were all subjects of independent learning. CLIL emphasizes that students learn and use language at the same time as they learn subjects. In a CLIL classroom, the curricular subject and new language are taught together. Students are motivated by interesting subject content to learn and use target language. Students' understanding of the subject content is the main focus but the teaching of non-native language is also an important part of CLIL.
All CLIL courses are designed to increase students' knowledge of the subject area while improving their knowledge and skills in the target language. In the meantime, "culture" plays an important part of CLIL. Students should value, understand and appreciate different cultures. Having positive attitudes, students enhance international and local cultural awareness while learning subject content through non-native language.

Environmental Ecology is a subject related to all living creatures, human activities and their interrelationship with the environment. Nowadays, the subject has developed into a study to give directions to the sustainable development of ecosystem and human activities [3]. Besides teaching students the subject contents and cultivating their cognitive or thinking skills, teachers also should have students become awareness of their responsibilities of global and local citizenship. Therefore, this study, based on 4Cs-Framework, provides a CLIL lesson about oxidation pond in Environmental Ecology to improve students' performance in both the curricular subject and the target language, and simultaneously build a stronger link between students and world where they live as global citizens. 


\section{THE ROLE OF LANGUAGE IN A CLIL CLASSROOM}

In 4Cs-Framework, Meyer suggests that "interaction in the learning context is fundamental to learning." [2] The language needs to be learned is related the learning context. Teachers need to encourage students to take part in meaningful interaction in the classroom. CLIL language communication learning is divided into three categories (see Figure 1): Language of Learning, Language for Learning and Language through Learning [1]. The three parts are intertwined in the lesson plan of Environmental Ecology to reach the goal "using language to learn" and "learning to use language."

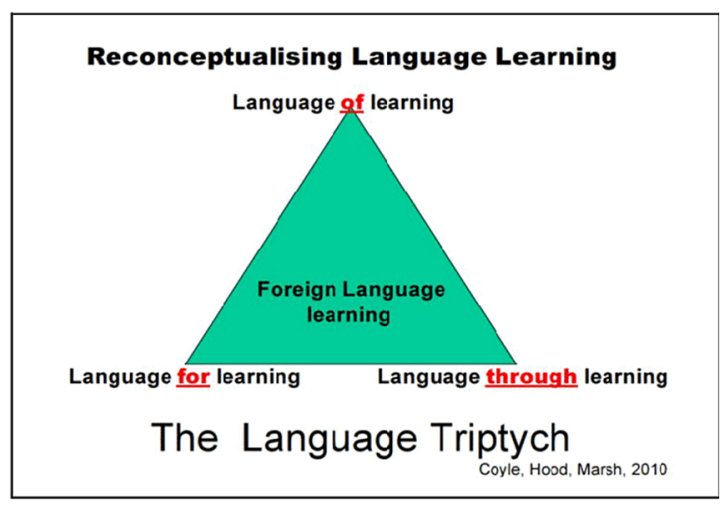

Fig 1. Source: Coyle, Hood, Marsh 2010

1) Language of Learning involves the specific professional knowledge or terminology of the discipline. In Environmental Ecology CLIL courses, language communication in this part should deal with vocabulary related to environmental biotechnology such as "oxidation pond," "aerobic", "facultative", "maturation", "anaerobic", etc. Through highlighting the related vocabulary and chunks of vocabulary used in class, students could have a wide range of vocabulary they need when expressing subject content.

2) Language for Learning emphasizes the language that used by teachers to guide students as well as that used by students to do group discussions and cooperative learning activities. The teacher can provide some specific sentence patterns for students to participate in classroom learning. For example:

- How do you spell the word

- What is ?

- $\quad$ is technique used to

- Compared to , it can

Teacher needs to plan opportunities for students to develop their communication skills within classroom. The interactive English helps increase student talking time and supports students to communicate their ideas or opinions about the subject content effectively.

3) Language through Learning highlights that students, in the spiral learning process, students, based on what has been learned, can learn, think, ask for information actively through target language. This part of language acquisition needs to be generated through classroom peer or teacher-student interaction. The words and sentences students inadvertently speak in class are not predictable to the teacher showing that students develop the ability to construct a new language and acquire new knowledge by themselves. Language through Learning is unique in CLIL classroom where students can express their own thoughts or opinions in English in a contextual environment.

The purposes of using CLIL language teaching methods aim to connect learners' existing learning knowledge and experiences, and to provide students with more different language materials which are not limited in language courses. In other words, CLIL extends language learning to other subject areas. The role of bilingual practices in CLIL starts to attract attention. The use of L1, code switching, language alternation, or translanguaging are under discussions to know how they help students in knowledge acquisition [4]. CLIL intends increasing students' exposure to a new language rather than replace the language they are familiar with.

Learning subjects through a foreign language is challenging to students. Code switching in CLIL is not uncommon and it is also viewed as a scaffolding advice for the learning of new subject content [5]. To make sure that students learn the subject content well, effective scaffolding helps students form ideas and acquire new language. The following section discusses scaffolding learning in Environmental Ecology CLIL teaching.

\section{SCAFFOLDING LEARNING}

In the CLIL classroom, the relationship between subject content and language is a challenge to the subject teacher as well as the language teacher. CLIL teaching focuses on subject content. When English is added as the teaching medium, students may face new challenges and obstacles in learning. Therefore, it is necessary to provide scaffold learning in the curriculum design. Appropriate

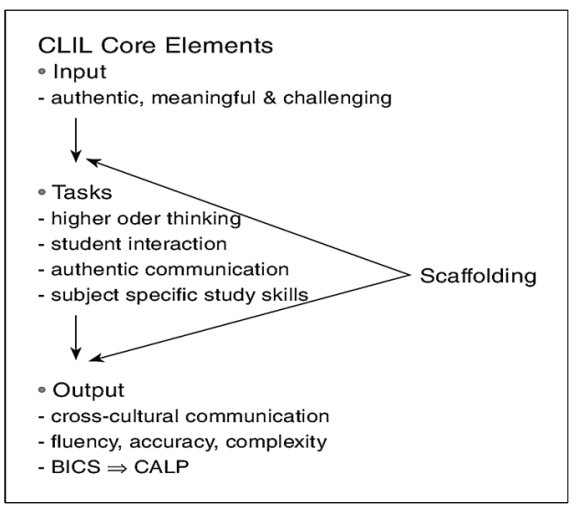

Fig 2. CLIL core elements COliver Meyer 
and timely assistance can help students reduce anxiety and cultivate self-confidence. CLIL curriculum design is to help students' learning, whether it is the part of language or that of subject content.

As what Meyer indicates in the CLIL core elements (see Fig 2.), meaningful and authentic input determines the successful acquisition of foreign language [2]. Scaffolding helps students acquire cognitive academic language efficiently. He suggests that subject learning through a foreign language works best when new topics are presented in a way that students can link new input to their prior knowledge or experiences. Meyer argues that scaffolding reduces the cognitive and linguistic load of the content/input. With the help of quantity and intensity of scaffolding, students can understand content and language input of all sorts. The task-based class activity would not become pressure to students to fulfil. On the contrary, they can develop communication skills and thinking skills to accomplish a given task. The teacher's appropriate use of the language triptych enables students' language production, that is, students can verbalize their thoughts to the subject content.

The study takes the Environmental Ecology lesson of oxidation pond as an example. In the scientific education, the material contains more lexical items than students are familiar with and thus becomes the cognitive load for them to understand how oxidation pond works. It is not unsuitable for CLIL classroom to have unfamiliar vocabulary. Instead, students should not fear the unknown words and structures related to subject materials psychologically. To help students construct their own learning, teachers can provide proper learning skills and strategies to promote students' language, higher order and critical thinking skills.

CLIL teachers can use resources such as posters, flashcards, pictures or diagrams to support learning. To teachers or students, the use of multi-media is helpful in learning subject content and target language. Multimedia includes the use of audio, video, graphics, text, animation, etc. Teachers make a good use of these teaching aids which can reach an interactive CLIL classroom. Students can connect knowledge and ideas, understand the presented information, and further produce oral and written language. Through meaningful and systematic practice based on scaffolding, students have higher motivation for language learning and produce a quality output [2].

The following section is the Collaborative Teaching of the language teacher and the subject teacher on the topic of oxidation pond. Oxidation ponds provide great economic, social and ecological benefits which profoundly connects to human being's activities and environment. Students will learn the works of oxidation ponds, the related academic language use and critical thinking skills.

\section{COLLABORATIVE TEACHING IN CLIL CLASSROOM}

Collaborative Teaching, or team teaching, is defined as two teachers to plan, organize, instruct and make assessments on the same group of students, generally in a common classroom. This teaching method often occurs in various disciplines. Co-Teachers collaborate within the classroom environment to support language learners and content integration [6]. Therefore, collaborative teaching can be implemented across all instructional levels and subject areas. In the Environmental Ecology CLIL classroom, collaborative teaching benefits students' understanding and achievement in subject content and academic language use.

The subject teacher and the English teacher in charge of Environmental Ecology classes meet once a week to coordinate course content. The English teacher must first translate the content of the Environmental Ecology curriculum that was originally in Chinese into English. In the first or second period of the course, the English teacher will first teach the English of the specific words of the unit, and the subject teacher is responsible for the content part. With this collaborative teaching, students learn the subject-specific language first, and the subject teacher does not have to spend time teaching academic language in class.

To reduce students' cognitive and linguistic load, the Environmental Ecology courses tends to soft CLIL but adopted subject-led type of CLIL, namely some parts of the subject syllabus are taught in target language. Through progressive fusion, the course gradually increases the linguistic proportion of the content. Twenty percent of foreign language teaching is used in one class in the initial stage. With the help of inputscaffolding, students understand the content and language easier. The topic of the CLIL class is the introduction of oxidation ponds. The subject teacher introduces the characteristics of oxidation ponds and the ecosystem of the ponds. The teaching procedure is designed as the following:

1) Prior knowledge: students understands the definition and the goal of "ecological engineering" and how it applies to solve environmental pollutions.

2) Linguistic ability: students need to understand and produce subject-specific vocabulary of the subject content to communicate ideas and interpret diagrams. The key vocabulary includes stabilization, oxygen, algae, bacteria, aerobic, facultative, maturation, anaerobic, photosynthesis and degradation. 


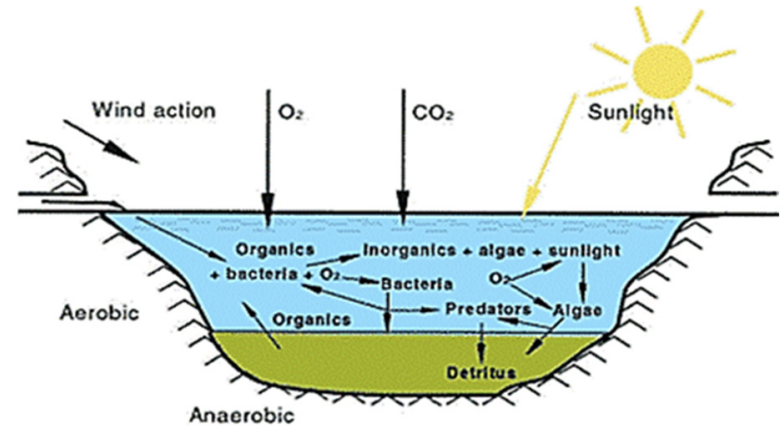

Fig 3: Facultative pond Source: Water treatment website (2016)

3) Theory of oxidation ponds: to have a better input of the subject content as well as to provide scaffolding learning, the subject teacher can take advantage of diagrams or pictures (see Fig 3) to illustrate the content which can promote students' target language learning and acquisition of subject knowledge. In addition, the subject teacher can explain the types and works of oxidation pond in Chinese or through bilingual learning at the right time with the help of language teacher.

4) Task discussions: it is important to increase student talking time which greatly improves their language learning. The teacher can have group discussions like "What are the types of oxidation pond?" "How does the pond work?" or "What are the advantages of various oxidation ponds?" Students can communicate subject content orally and develop speaking and listening strategies. Furthermore, the teacher's application of open questions rather than closed ones can help students clarify their concepts and develop thinking skills.

5) Wrap up: with the help of diagram, the teacher reviews the formation of oxidation pond and asks students to share their answers about its advantages. Students review subject content and the subjectspecific vocabulary again.

Teachers should timely assist students when they summarize and demonstrate in incomplete expressions. When students become familiar with the classroom language as well as the academic language. It would become easier for them to understand subject content and fulfil the assigned tasks. Meanwhile, teachers should raise students' awareness of environmental sustainability. Eco-culture is "a moral and humanistic norm of interaction and communication of human and the environment" [7]. Students should understand the eco-culture of their own country and furthermore pay heed to worldview on the ecosystem and human activities.

\section{CONCLUSION}

As a form of bilingual education, CLIL is used as the language of instruction in school subjects. The CLIL classroom provides a context for meaningful language learning and use. CLIL curriculum design attempts to help teachers and students on the teaching aims and the learning outcomes respectively in terms of content, communication, cognition and culture. Interdisciplinary teaching needs teachers to collaborate to make subject content presented in an understandable way.

Environmental Ecology is a subject that shows the interrelations between a human and the world. Through the teaching of oxidation pond, students learn how this ecosystem can effectively purify and comprehensively utilize various pollutants in sewage. They also learn the food chain of the oxidation pond. It can not only achieve great economic, social and ecological benefits, but also avoid climate disasters and achieve sustainable development goals. With meaningful input can students acquire subject knowledge and linguistic ability and then produce rich output.

A successful CLIL project requires a cooperation which means that content teachers and language teachers must have a way to cooperate with each other, such as regular meeting and coordinating courses. Techers can scaffold learning so that students would have higher motivation and constructive outcome in the learning process. Students, with lower psychological burden, can enjoy learning in an interactive and collaborative classroom that enables them to understand content knowledge, improve language abilities and appreciate different cultures during the learning process.

\section{REFERENCES}

[1] D. Coyle, P. Hood, D. Marsh, CLIL: Content and Language Integrated Learning. Cambridge: CUP, 2010 .

[2] O. Meyer, Introducing the CLIL-Pyramid: key strategies and principles for CLIL planning and teaching, M. Eisenmann and T. Summer (Eds), Basic Issues in EFL Teaching, pp.295-313. Universitätsverlag Winter GmbH Heidelberg, 2013.

[3] S. G. Lu, Environmental Ecology, Zhejiang: Zhejiang University Press, 2010.

[4] T. Nikula, CLIL: A European approach to bilingual education. N. Van Deusen-Scholl, and S. May (Eds). Second and Foreign Language Education, pp. 1-14. 2017. DOI:10.1007/978-3-319-023236_10-1

[5] E. Gierlinger, 'You can speak German, sir': on the complexity of teachers' L1 use in CLIL, Language and Education. Language and Education. Vol. 29: 4, pp. 347-368. 2015. DOI: $10.1080 / 09500782.2015 .1023733$ 
[6] L. Valdés-Sánchez, M. Espinet, Coteaching in a science-CLIL classroom: changes in discursive interaction as evidence of an English teacher's science-CLIL professional identity development, International Journal of Science Education, vol. 42: 3 ,

PP.

27. DOI:10.1080/09500693.2019.1710873

[7] E. Barkova, O. Buzskaya, M. Ivleva, M. Buzskij, Ecology of culture in the space of social and humanitarian knowledge. in: Proceedings of the International Conference on Contemporary Education, Social Sciences and Humanities (ICCESSH). Paris: Atlantis Press, 2017, vol. 124, pp. 12-15. 